\title{
Evaluation of energy requirements of an industrial scale plant for the cultivation of white button mushroom (Agaricus bisporus)
}

\author{
Roberto Beghi, Valentina Giovenzana, Alessio Tugnolo, Domenico Pessina, Riccardo Guidetti \\ Department of Agricultural and Environmental Sciences - Production, Landscape, Agroenergy, Università degli Studi \\ di Milano, Milano, Italy
}

\begin{abstract}
The white button mushroom (Agaricus bisporus) industry is paying attention to innovation for a more sustainable production and it is getting sophisticated to reach high grade of energetic efficiency coupled with high quality product. For mushroom cultivation the environmental conditions must be controlled therefore in some phases the heat needs to be provided and in other ones it needs to be removed. The objective of this study was to investigate the current growing methodology used at an industrial mushroom farm site for a quantification of energy consumption. Mushroom growing parameters such as temperature and relative humidity were monitored during the production process placing sensors for a continuous data recording of these parameters in different and crucial positions throughout the entire production cycle. Heat is massively produced by the compost/mycelium system and the goal was to quantify the amount of energy needed to remove it through a cooling system and a forced air system that pulls cold air in the cultivation room and picks up the warmer and more humid air. Often, the heat produced by the cultivation room is not enough to reach the optimal growth conditions. In this case the application of an air heating system is necessary. The study was focused on evaluating the energy exchanges during a 41-day period corresponding to a growth cycle of three flushes to quantify the energy requirements of the conditioning system. A total energy of
\end{abstract}

Correspondence: Valentina Giovenzana, Department of Agricultural and Environmental Sciences - Production, Landscape, Agroenergy, Università degli Studi di Milano, via Celoria 2, 20133, Milano, Italy.

E-mail: valentina.giovenzana@unimi.it

Key words: Champignon; energy analysis; cultivation; cooling; heating; sustainability.

Acknowledgements: The authors acknowledge 'Fungorobica srl' mushroom company (Cenate Sotto, Bergamo, Italy) for the support during the experimentation and dr. Renato Tibiletti and dr. Alessandro Barucci for the technical support.

Received for publication: 9 July 2019.

Accepted for publication: 26 January 2020.

(C) Copyright: the Author(s), 2020

Licensee PAGEPress, Italy

Journal of Agricultural Engineering 2020; LI:1000

doi:10.4081/jae.2020.1000

This article is distributed under the terms of the Creative Commons Attribution Noncommercial License (by-nc 4.0) which permits any noncommercial use, distribution, and reproduction in any medium, provided the original author(s) and source are credited.
$5483 \mathrm{kWh} /$ cycle was quantified for a mushroom production of $25,000 \mathrm{~kg}$, corresponding to a specific energy requirement of 0.22 $\mathrm{kWh} / \mathrm{kg}, 0.18$ for cooling and 0.04 for heating. Results showed that the electric power consumption represents a crucial cost for the mushroom production, therefore an optimization of the energy requirements of the production plant is desirable and it can lead to relevant economic savings. A scenario considering a more efficient air conditioning system was proposed for a more sustainable mushroom production.

\section{Introduction}

White button mushroom (Agaricus bisporus), most commonly named champignon, production is a growing industry with good perspectives of further increase in the future thanks to the attention to its nutritional value, in particular to protein-rich content (Raghavendra et al., 2017).

Mushrooms' market is experiencing a big increase all around the world, but the largest expansion is localized in China, which accounts for more than $85 \%$ of the total worldwide production amounting to 34 million tons produced in 2013; the annual crop income was 3.2 billions of dollars worldwide in 2009 and is now more than 4 billion dollars (Sonnenberg et al., 2017). The Agaricus bisporus, being the most cultivated mushroom species worldwide, contributes about $40 \%$ of the total world mushroom's production (Giri et al., 2009; Sonnenberg et al., 2017).

The increasing mushroom world-wide production induces higher expectations for its quality. Consequently, the distribution channel (DC) and the final consumers become more critical and are ready to pay more for a product with higher quality (V'́zhányó and Felföldi, 2000).

The white button mushroom industry is paying attention to innovation for a more sustainable production and it is getting sophisticated to reach high grade of energetic efficiency coupled with high quality product. Mushrooms are cultivated on organic waste mainly composed of lignocellulosic biomass leading to an agro-wastes valorisation. Moreover, recent research on the technology of substrate making and cultivation has opened new possibilities for the production of this mushroom considering: i) high yield of conversion of raw ingredients to edible product; ii) limited use of pesticides for controlling pests and pathogens; iii) decreasing the consumption of energy by cultivating strains adapted to various climatic conditions; and iv) greater access to technological innovations (Savoie and Mata, 2016). Controlling all the parameters of the cultivation room such as temperature, relative humidity, and carbon dioxide levels is essential for the correct colonization of the compost by the mushroom's hyphae. The primordia (i.e. the mushrooms in their early stage of development) that appear on the casing layer are called pin, pinhead, or knot and have 3-4 mm diameter. The autumn approaching simulation con- 
sists in decreasing the temperature gradually from $25^{\circ} \mathrm{C}$ to $18^{\circ} \mathrm{C}$, decreasing the $\mathrm{CO}_{2}$ levels (optimum $0.1-0.5 \%$ ) by ventilating fresh air from outside (filtered air), and in increasing the relative humidity (San Antonio and Thomas, 1972; Straatsma et al., 2013). Fruiting begins after the $3^{\text {rd }}$ week and can be followed by other two or three flushes over one production cycle. During a flush the mushrooms grow rapidly, doubling their size every $24 \mathrm{~h}$, and must be harvested before they start releasing new spores. The cropping is usually carried out by careful hand harvesting because every fingerprint can leave marks on mushroom's hat causing a decrease of quality. The chart reported in Figure 1 summarizes the optimal growing condition for a hybrid strain of Agaricus bisporus as suggested by a leader production company from The Netherlands (Hollander Spawn, 2017; http://www.hollanderspawn.com). Several variables are involved in Agaricus bisporus growth process, and the control of each of them is mandatory to obtain a high yield with the lower possible expenses.

The cultivation room is a closed environment where all kind of contamination must be avoided to obtain a healthy product. Before starting a new cultivation cycle, each room is sterilized with the injection of high temperature vapor $\left(70^{\circ} \mathrm{C}\right)$ for $4-5 \mathrm{~h}$. Mushroom compost is a fertile substratum for diseases such as viruses, bacteria, fungi, nematodes, and insects causing a high risk of epidemics. The hygiene of the mushroom farm is extremely important for preventing a pest outbreak.

The metabolic heat removal from the system compost/ hyphae/soil is performed by the air flow generated by the ventilation system and the cooling plant. The evaporation rate is con- trolled by the capacity of the ventilation system to quickly circulate air and by its capacity of removing humidity levels. When it gets too fast or when the relative humidity is too low, the compost loses too much water and dries up causing mycelium stress damage. On the contrary, if there is too much water the mycelium suffers the lack of oxygen causing anaerobic damage; when the relative humidity is too high the water is not capable to evaporate anymore stopping heat dissipation. Water is a variable that heavily influences the mushroom final yield.

Traditional cultivation plants are characterized by growing methods of the Agaricus bisporus typically based only upon experience and not on scientifically consolidated data. So, the design of the conditioning systems is not based on measured data of the real heating/cooling load requirement. This can lead to problems of under-sizing or oversizing of the plant resulting in problems of correct production or energy efficiency of the process, respectively.

Moreover, very few studies are available in literature concerning energy consumption and efficiency evaluation of the industrial mushroom production. Gunady et al. in 2012 studied the global warming potential of the fresh produce supply chain for strawberries, romaine/cos lettuces (Lactuca sativa), and button mushrooms (Agaricus bisporus) in Western Australia using life cycle assessment (LCA). Results showed that the life cycle GHG emissions of strawberries and lettuces were higher than mushrooms due to intensive agricultural machinery operations during the on-farm stage, while mushrooms have significantly higher GHG emissions during pre-farm stage due to transport of peat, spawn, and compost. For mushroom cultivation the environmental conditions must

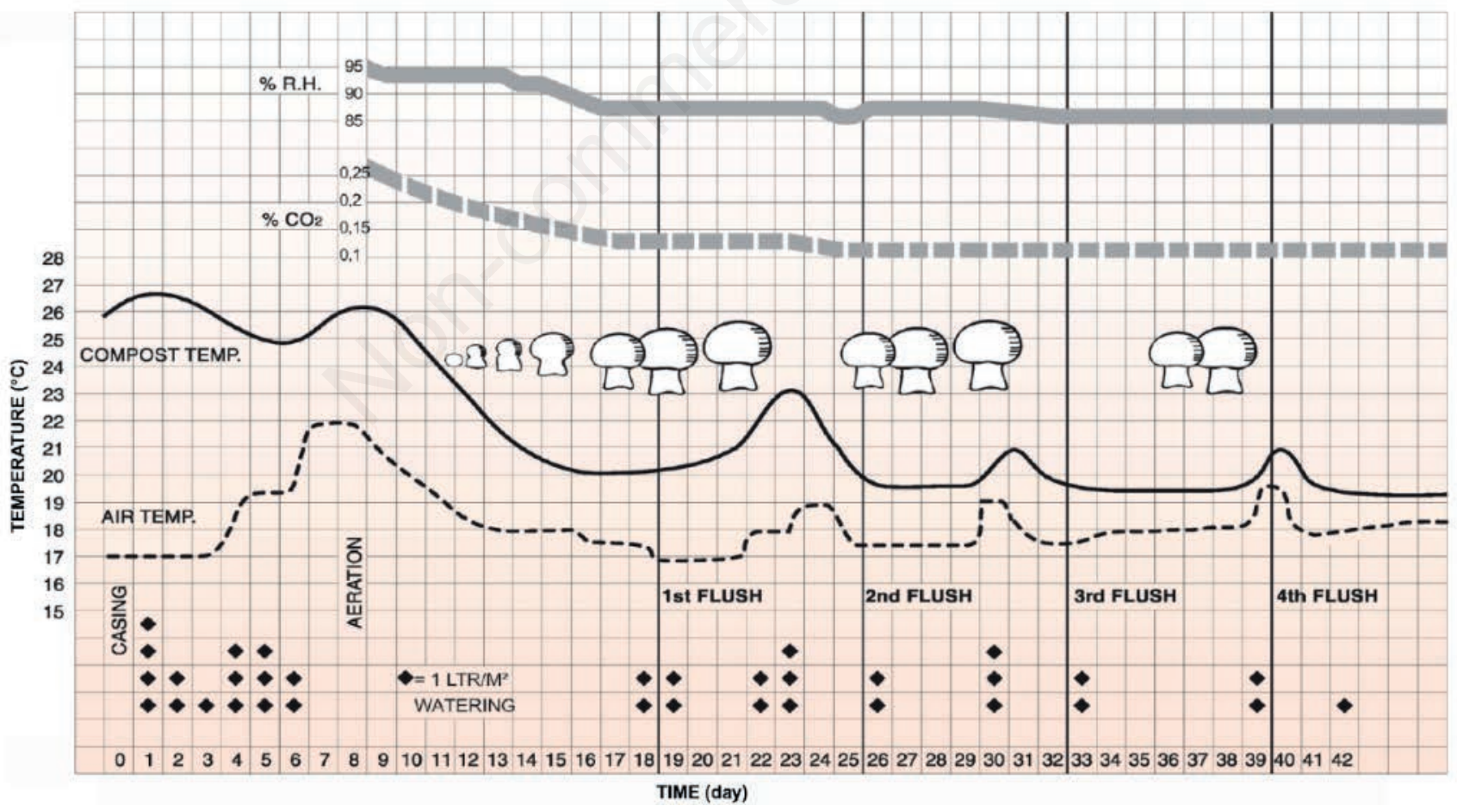

Figure 1. Chart summarizing the evolution of the pivotal parameters for an entire mushroom growing cycle. The black line represents the optimal compost temperature throughout the whole growth cycle. The dashed line represents the ambient air temperature that follows in parallel the compost temperature line. The black dots indicate the amount of water, with each dot corresponding to $\mathrm{dm}^{3} \mathrm{~m}^{-2}$, required for an optimal final yield. It also indicates the exact days when the watering should be carried out. Finally, the two grey lines illustrate the optimal values of relative humidity (continuous line) and $\mathrm{CO}_{2}$ level (dashed line) (Hollander Spawn, 2017; available from: http://www.hollanderspawn.com). 
be controlled therefore in some phases the heat needs to be provided and in other ones it needs to be removed. Monitoring an industrial-sized plant is more complicated than monitoring a laboratory pilot-sized plant. The objective of the study was to investigate the current growing methodology used at an industrial mushroom farm site for a quantification of heating/cooling energy demand from data measured inside the cultivation room. Agaricus bisporus mushroom growing parameters such as temperature and relative humidity were monitored during the production process placing sensors for a continuous data recording of these parameters in different and crucial positions inside the room throughout the entire production cycle. The study was focused on evaluating the energy exchanges during a growth cycle of three flushes to quantify the heating/cooling energy demand related to mushroom cultivation. Finally, a scenario was envisaged considering the use of a more efficient heating/cooling system for a more sustainable production.

\section{Materials and methods}

Heat is massively produced by the system compost/mycelium and the goal was to quantify the amount of energy needed to dissipate it. Heat removal is obtained through a cooling system and a forced air system that pulls cold air in the cultivation room and picks up the warmer and more humid air. Often, the heat produced by the cultivation room is not enough to reach the optimal growth conditions. In this case the application of an air heating system is necessary. Moreover, the air flow rate was measured at different points of the system, hence the energy requirements of the heating/cooling system was quantified during the process.

\section{Cultivation room}

The experimentation took place at Fungorobica srl mushroom company (Cenate Sotto, Bergamo, Italy). The company is experiencing an internal evolution focused on bringing their production methods up to date, paying attention to technological innovation and energetic optimization. The facility is composed by 8 rooms positioned side by side, each containing 6 cultivation beds in four rows for a total of $6021.1 \mathrm{~m}^{2}$ of potentially exploitable surface. Each cultivation room measure $262.8 \mathrm{~m}^{2}$, without windows. Every row of beds is equipped with a manually operated adjustable scaf- folding platform that can be used for irrigation and mushroom picking. The beds are made of steel which allow to bear the high weight of the compost that can be loaded to $130 \mathrm{~kg} \mathrm{~m}^{-2}$. The bottom of each bed presents a steel grid to facilitate water outflow and to avoid stagnation (and anaerobiosis) (Figure 2A).

The measures of each room are: length: $21.9 \mathrm{~m}$, width: $12.0 \mathrm{~m}$, height: $5.8 \mathrm{~m}$, for a volume of $1524.2 \mathrm{~m}^{3}$ each one. The measures of the beds are: length: $19.6 \mathrm{~m}$, width: $1.6 \mathrm{~m}$, height: $0.3 \mathrm{~m}$.

The harvest is carried out by careful hand harvesting and a simultaneous visual selection of defective mushrooms is performed by expert operators. The relatively short shelf life of mushrooms, up to 6-8 days, depends on the storage condition of relative humidity and temperature.

\section{Temperature conditioning system}

All utilities in the plant requiring temperature control were served by a centralized electric conditioning system which supplied a closed-loop conditioning circuit for air treatment coupled with an aeration system for the conditioning of the rooms (Figure $2 \mathrm{~B})$. The system is equipped with an automated control system for the setting of the desired temperature profile in the cultivation room. The system provides also heating load. The inlet air flows into the room at constant speed through two plastic flexible ducts running $0.30 \mathrm{~m}$ from the ceiling for all the length of the room before being deviated back into other three ducts, one in the centre and two at the sides of the room (Figure 2B). The aeration ducts are made of polyolefin resin and present holes for air adduction on the top and bottom side. To reach homogeneously every part of the room, each duct runs parallel to one of the corridors between the bed rows, promoting the heat exchange with soil and compost. The diameter of each tube is $0.55 \mathrm{~m}$, the section is $0.24 \mathrm{~m}^{2}$ and each air adduction hole diameter is $0.05 \mathrm{~m}$.

\section{Data measurement}

\section{Hot-wire anemometer}

The air speed was measured using a hot-wire anemometer (Giovenzana et al., 2013; ASHRAE Handbook Fundamentals, 2009). The rectangular section of the air flow opening was central positioned on the back wall, $0.5 \mathrm{~m}$ from the floor, and equal to $0.473 \mathrm{~m}^{2}$. The air speed value ( vair, $\mathrm{m} \mathrm{s}^{-1}$ ), multiplied to the aspiration air vent section $\left(\mathrm{A}, \mathrm{m}^{2}\right)$, allows to calculate the aspiration's
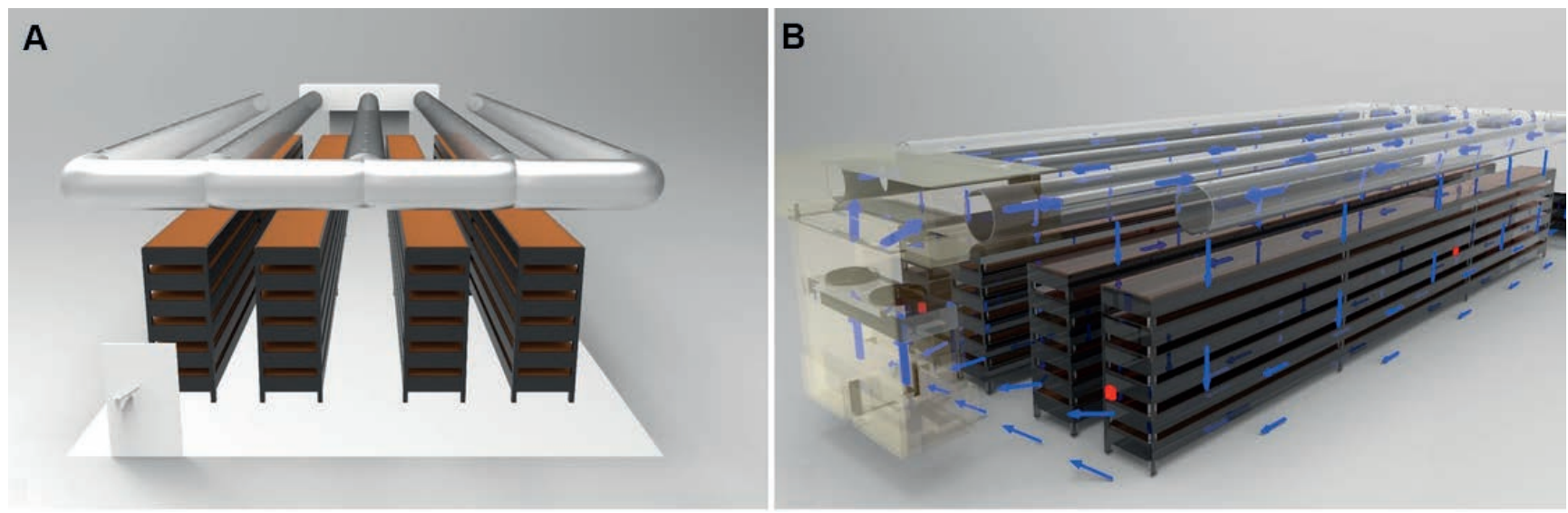

Figure 2. Rendering of a cultivation room (A) and scheme of the ventilation flow (B). 
air flow rate $\left(\mathrm{Q}_{\mathrm{a}} ; \mathrm{m}^{3} \mathrm{~s}^{-1}\right)$, according to the following formula (1):

$\mathrm{Q}_{\mathrm{a}}=\mathrm{v}_{\text {air }} \mathrm{A}$

Air speed data were taken inside the room in correspondence of the inlet duct and from the outlet duct. 10 repetitions for each of the 5 measuring positions were carried out for collecting an accurate measure of the air's turbulent flow.

\section{Temperature and humidity sensors}

In order to trace the variation of environmental temperature $\left({ }^{\circ} \mathrm{C}\right)$ and relative humidity $(\%)$ inside the cultivation rooms, 4 sensors (Econorma FT-102, dual-channel data logger of temperature and relative humidity, Treviso, Italy) were positioned in crucial spots. The sensors were located at the inlet air to the room and at the return air from the room to record data for the duration of an entire production cycle. Sensors were synchronized and set up to record one data every $10 \mathrm{~min}$.

\section{Data processing}

The aim was to quantify the total heating/cooling load and energy demand associated with a production cycle of 41 days. The studied cycle was carried out in October 2018, outside temperature ranged between $11.9^{\circ} \mathrm{C}$ and $20.4^{\circ} \mathrm{C}$, with a mean value of $15.7^{\circ} \mathrm{C}$. The heat exchanged by the walls of the room in this period tends to cancel out and it could be considered as negligible. The electric energy consumption of the air conditioning system (the compressor for the cooling and the electrical resistance for the heating) was calculated. No measurements were performed on fans. The methodology is based on the calculation of enthalpy variation inside the room in which takes place a biological process that develops heat (e.g. a fermentation tank) (Colombié et al., 2007). The heat accumulated by the cultivation room includes mainly the heat generated by compost/mycelium system due to exothermic reactions related to compost fermentation and mushrooms metabolism during the growing process and the heat lost by evaporation of water during the irrigation routines (Colombié et al., 2007; Giovenzana et al., 2016). The heat accumulated must be controlled using a conditioning system capable of maintaining the correct air temperature inside the room based on the specific Agaricus bisporus requirements.

The mass of the mushrooms produced during the 3 flushes of the cycle was measured $(\mathrm{m}, \mathrm{kg})$. The enthalpy values of the inlet air to the room $\left(\mathrm{H}_{\mathrm{in}}, \mathrm{kJ} \mathrm{kg}^{-1}\right)$ and the one of the return air from the room $\left(\mathrm{H}_{\text {out }}, \mathrm{kJ} \mathrm{kg}^{-1}\right)$ were calculated from inlet and return air temperature and air relative humidity ( $\mathrm{T}_{\text {in }} \mathrm{RH}_{\text {in }} \mathrm{T}_{\text {out }} \mathrm{RH}_{\text {out }}$, Table 1) recorded for each sampling point, and the difference $\mathrm{H}_{\text {out }}-\mathrm{H}_{\text {in }}$ was calculated $\left(\Delta \mathrm{H}, \mathrm{kJ} \mathrm{kg}^{-1}\right)$, using a calculator program reproducing the Mollière diagram. The total heating/cooling load $(\mathrm{kW})$ was calculated considering the air flow into the room $\left(\mathrm{F}_{\text {air }}, \mathrm{kg} \mathrm{s}^{-1}\right)$ and $\Delta \mathrm{H}$. The total heat provided/removed from the plant $\left(\Delta \mathrm{Q}_{\mathrm{acc}}, \mathrm{kWh}\right)$ during the cycle was quantified using the cycle time (t, h) (Eq. 2).

$$
\Delta Q_{a c c}=\left(\sum_{i=1}^{n} F_{a i r} \cdot \Delta H_{i}\right) \cdot t
$$

The cultivation temperature of the mushrooms must always be controlled to obtain an optimal production. The heat produced by mushrooms can be excessive, implying a high temperature and therefore the cultivation room must be cooled by heat subtracting with the cooling process. If, on the other hand, the heat produced is not enough to maintain the temperature necessary for the optimal production, the cultivation room must be heated by using the electric resistance. Therefore, the air conditioning system consists of a refrigeration unit and a heating unit. The studied industrial plant is equipped with a compressor, the only energy-intensive part of the cooling system, and an electric heating element.

The electric energy consumption of the industrial plant was calculated and compared with electric energy attributable to a more efficient system. Since cooling and heating are never necessary simultaneously, as more efficient system, it was decided to envisage the use of a heat pump, capable to subtract and produce heat. The efficient system would be equipped with a reverse-cycle heat pump to subtract and produce heat with the same machine estimating the COP of the heat pump and $\varepsilon$ of the chiller as indicated in Table 2. Moreover, energy and economic savings between the studied air conditioning system (traditional scenario) and the efficient air conditioning system (efficient scenario) was carried out.

Electric energy consumption and related costs were estimated

Table 1. Input data for energy analysis.

\begin{tabular}{lc} 
Parameter & Symbol \\
Mushrooms yield $(\mathrm{kg})$ & $\mathrm{m}$ \\
Air temperature, return $\left({ }^{\circ} \mathrm{C}\right)$ & $\mathrm{T}_{\text {out }}$ \\
\hline Air temperature, inlet $\left({ }^{\circ} \mathrm{C}\right)$ & $\mathrm{T}_{\text {in }}$ \\
Relative humidity air, return & $\mathrm{RH}_{\text {out }}$ \\
\hline Relative humidity air, inlet & $\mathrm{RH}_{\text {in }}$ \\
Process time $(\mathrm{h})$ & $\mathrm{t}$ \\
\hline Circulating air speed $\left(\mathrm{m} \mathrm{s}^{-1}\right)$ & Vair \\
Volume of cultivation room $\left(\mathrm{m}^{3}\right)$ & $\mathrm{V}$ \\
\hline
\end{tabular}

Table 2. Estimated values of parameters and calculation for electric energy consumption estimation of the studied industrial plant and of the air conditioning system envisaged in the efficient scenario.

\begin{tabular}{lccc} 
Parameters & Symbol & Traditional scenario & Efficient scenario \\
Refrigeration efficiency coefficient & $\boldsymbol{\varepsilon}$ & 3 & 4 \\
Electric efficiency & $\eta_{\mathrm{e}}$ & 0.9 & 0.9 \\
\hline Mechanical efficiency & $\eta_{\mathrm{m}}$ & 0.6 & 0.7 \\
Heating system efficiency & $\eta_{\mathrm{s}}$ & 1 & 5 \\
\hline Heat pump performance coefficient & $\mathrm{COP}$ & & \\
Compressor electric energy & & Cooling energydemand $/ \boldsymbol{\varepsilon}^{*} \eta_{\mathrm{el}}{ }^{*} \eta_{\mathrm{m}}$ & \\
Resistance electric energy & & Heating energy demand $/ \eta_{\mathrm{s}}$ & Heating energy demand $/ \mathrm{COP}^{*} \eta_{\mathrm{el}}{ }^{*} \eta_{\mathrm{m}}$ \\
Heat pump electric energy & & &
\end{tabular}


considering: i) the refrigeration efficiency coefficient for air cooling $(\varepsilon)$ for the studied air conditioning system; ii) the electric efficiency $\left(\eta_{\mathrm{e}}\right)$; iii) the mechanical efficiency $\left(\eta_{\mathrm{m}}\right)$; and iv) the heating system efficiency $\left(\eta_{\mathrm{s}}\right)$ (Table 2 ). Moreover, calculations according to Table 2 were performed.

\section{Results and discussion}

Mushrooms from the three flushes were harvested by hand and put directly in the baskets ready to be weighed. Each basket was then stored up inside a fridge to preserve mushroom's freshness (Giovenzana et al., 2019). The net yield deriving from the trial (excluded all the defective mushrooms) was $25,000 \mathrm{~kg}$. Calculating the different enthalpy values of the air taken upon different points of interest, the quantity of heat subtracted (throughout refrigerator) or added (throughout electrical resistance) in each moment of the process was determined along with the corresponding heating/cooling energy demanded from the air conditioning system. The results of the air speed measured at the aspiration and inspiration tube of the cultivation room and the relative calculated air flow are displayed in Table 3. Figure 3 showed the air temperature profile, every $10 \mathrm{~min}$, inside the cultivation room for an entire mushroom growing cycle. The figure shows the temperature fluctuations over time required by the process.

The maximum value reached during the process was $24.4^{\circ} \mathrm{C}$, while the minimum $14.0^{\circ} \mathrm{C}$. An excel data sheet reproducing the Mollière diagram (Supplementary data) considering the air flow, was used to produce enthalpy values. The $\Delta \mathrm{H}$ used for the heating/cooling load measurement was calculated from the difference between $\mathrm{H}_{\text {out }}$ (air enthalpy after interacting with the cultivation room) and $\mathrm{H}_{\text {in }}$ (air enthalpy after treatment with the air conditioning system). Hence, the load related to the use of the air conditioning system for cooling, positive values, and heating, negative values the cultivation room is represented in Figure 4. Heating/cooling loads are calculated every 10 minutes as the temperature and humidity parameters have been measured with this time range. The load related to cooling reach a maximum of $18.47 \mathrm{~kW}$ while the maximum load required to heating correspond to $28.8 \mathrm{~kW}$. Considering the total amount of energy demand for heating/cooling the air of cultivation room, for the 41 days of the production cycle was $5482.3 \mathrm{kWh}$. A percentage equal to $74.3 \%$ of the energy (corresponding to $4517.9 \mathrm{kWh}$ ) was used to cool down the cultivation room, while $25.7 \%$ (corresponding to $964.4 \mathrm{kWh}$ ) was used for heating. Even if the air heating system requires more load, the cooling element consumes more energy because of the utilization time, minor quantity of cooling load for many minutes, respect to energy required from air heating system, major heating load for few time. Obviously, these percentages could vary according to the period of the year. To cancel out the gap due to the period of the year the experimentation was carried out in October, a month in which the temperature range can be considered as an annual average.

Based on the characteristics of the cultivation system (Table 4) loads, cooling and heating capacity, total energy demand by the air conditioning system (cooling and heating) for the optimal mushrooms growth of the studied plant was calculated. Furthermore, the electric energy consumption of the industrial plant was calculated (traditional scenario in Table 4) and compared with electric energy attributable to a more efficient system (efficient scenario in Table 4), equipped with a reverse-cycle heat pump.

Given the total mushroom production data of $25,000 \mathrm{~kg}$, dividing the total heating/cooling energy value found of 5483.8 $\mathrm{kWh} /$ cycle, it was estimated the energy required for the production in $0.22 \mathrm{kWh} / \mathrm{kg}, 0.18 \mathrm{kWh} / \mathrm{kg}$ for cooling and $0.4 \mathrm{kWh} / \mathrm{kg}$ for heating.

Electric energy consumption $\left(\mathrm{kWh}_{\mathrm{e}}\right)$ is the parameter necessary to calculate costs. It represents the main cost of mushroom production, optimizing its use (for example through installing more efficient motor and reverse-cycle heat pump) can lead to relevant and immediate economic savings.

The total electric energy $\left(\mathrm{kWh}_{\mathrm{e}}\right)$ deriving from traditional air conditioning system (compressor electric energy and resistance electric energy) and from efficient air conditioning system (Table $4)$, were multiplicate for the specific electric energy cost $\left(€ / \mathrm{kWh}_{\mathrm{e}}\right)$.

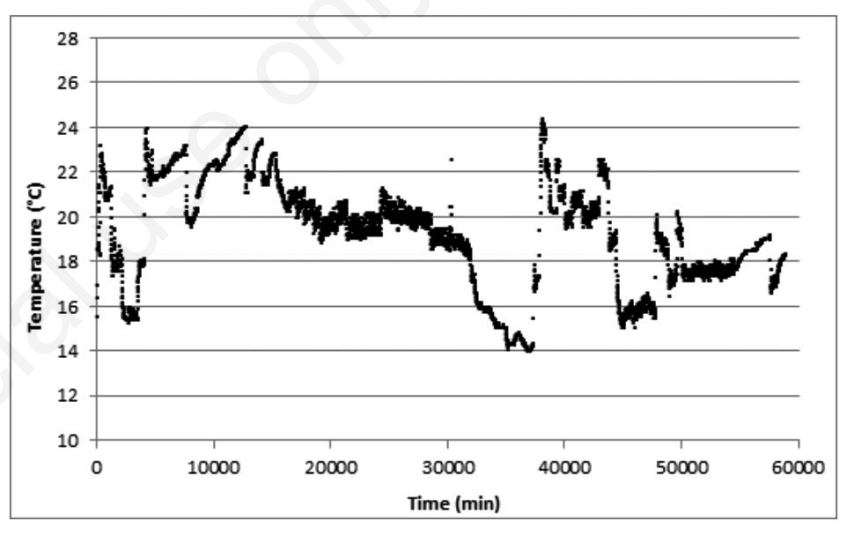

Figure 3. Air temperature profile, every $10 \mathrm{~min}$, inside the cultivation room during the mushrooms growing process.

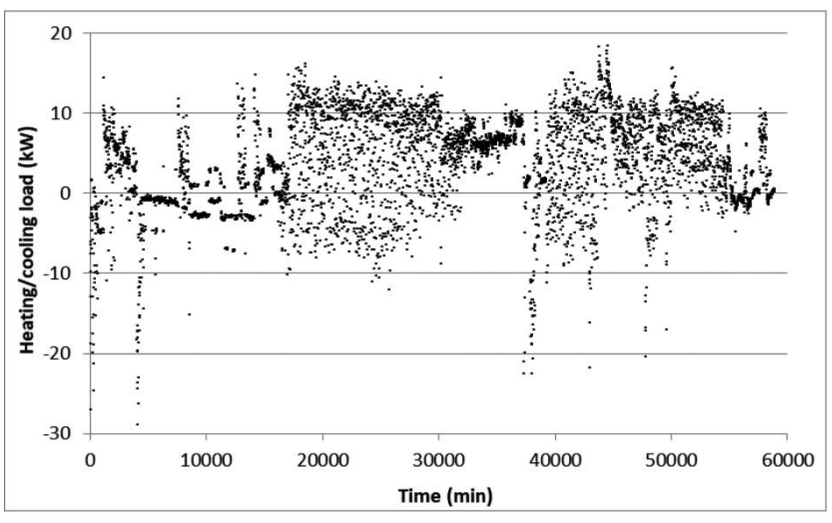

Figure 4. The load related to the use of the air conditioning system for cooling, positive values, and heating, negative values.

Table 3. Data measured with hot-wire anemometer to calculate air flow.

\begin{tabular}{lcccc}
$\begin{array}{l}\text { Parameters } \\
\text { Units }\end{array}$ & $\begin{array}{c}\text { Circulating air speed } \\
\mathrm{m} / \mathrm{s}\end{array}$ & $\begin{array}{c}\text { Specific volume } \\
\mathrm{m}^{3} / \mathrm{kg}\end{array}$ & $\begin{array}{c}\text { Aspiration section } \\
\mathrm{m}^{2}\end{array}$ & $\begin{array}{c}\text { Aspiration air flow rate } \\
\mathrm{kg} / \mathrm{s}\end{array}$ \\
\hline 5.2 & 0.825 & 0.47 & 2.98 \\
\hline
\end{tabular}


Table 4. Parameters related to air conditioning of mushroom cultivation room considering studied plant and the savings in comparison to the more efficient air conditioning system.

\begin{tabular}{|c|c|c|c|c|}
\hline Items & System & Parameters & Units & Values \\
\hline $\begin{array}{l}\text { Air conditioning heating/ } \\
\text { cooling load }\end{array}$ & Cultivation system & $\begin{array}{l}\text { Cooling load } \\
\text { Heating load } \\
\text { Cooling energy demand } \\
\text { Heating energy demand }\end{array}$ & $\begin{array}{l}\mathrm{kW} \\
\mathrm{kW} \\
\mathrm{kWh} \\
\mathrm{kWh}\end{array}$ & $\begin{array}{c}18.5 \\
28.8 \\
4517.9 \\
964.4\end{array}$ \\
\hline Energy & $\begin{array}{l}\text { Cultivation system } \\
\text { Traditional air conditioning system (traditional scenario) } \\
\text { Efficient air conditioning system (efficient scenario) } \\
\text { Saving }\end{array}$ & $\begin{array}{l}\text { Total energy demand } \\
\text { Specific energy demand } \\
\text { Compressor electric energy } \\
\text { Resistance electric energy } \\
\text { Total electric energy } \\
\text { Total electric energy } \\
\text { Energetic saving }\end{array}$ & $\begin{array}{l}\mathrm{kWh} \\
\mathrm{kWh} / \mathrm{kg} \\
\mathrm{kWhe} \\
\mathrm{kWhe} \\
\mathrm{kWhe} \\
\mathrm{kWhe} \\
\mathrm{kWhe}\end{array}$ & $\begin{array}{c}5482.3 \\
0.2 \\
2788.8 \\
964.4 \\
3753.2 \\
2099.0 \\
1654.3\end{array}$ \\
\hline Costs & $\begin{array}{l}\text { Traditional air conditioning system (traditional scenario) } \\
\text { Efficient air conditioning system (efficient scenario) } \\
\text { Saving }\end{array}$ & $\begin{array}{l}\text { System } \\
\text { Mushroom } \\
\text { System } \\
\text { Mushroom } \\
\text { Economic saving (system) } \\
\text { Economic saving (mushroom) }\end{array}$ & $\begin{array}{l}€ \\
€ / \mathrm{kg} \\
€ \\
€ / \mathrm{kg} \\
€ \\
€ / \mathrm{kg}\end{array}$ & $\begin{array}{l}563.0 \\
0.023 \\
314.9 \\
0.012 \\
248.1 \\
0.011\end{array}$ \\
\hline
\end{tabular}

Considering $0.15 € / \mathrm{kWh}$ for the electric energy cost (derived from the analysis of the average cost of electricity paid by the company), a cycle of 41 days costs approx. $563 € /$ cycle using traditional scenario and approx. $315 € /$ cycle supposing to adopt the efficient scenario. The efficient solution allows to save $248 € /$ cycle (44\%). Considering 6 cycles/year and the 8 rooms, it is possible to estimate a saving of $79,405 \mathrm{kWh}_{\mathrm{e}}$ corresponding to $11,904 € /$ year.

The hypothesis of using a more efficient air conditioning system is only a small step towards sustainable production. The cultivation and production of mushrooms involves many different operations, each of them requiring careful performance. The improvement of modern cultivation technologies, such as computerized control of production process, new methods for spawn preparation and substrates sterilization, and automated harvesting of mushroom fruit bodies, will increase the large-scale productivity of mushroom cultivation with lower costs than traditional technologies (Noble et al., 1997).

Some of the recent results regarding the modern technology and research are increasingly used in intensive cultures that ensure remunerative returns.

\section{Conclusions}

This study is focused on finding out how much cooling and heating load is needed to condition the cultivation room during the mushrooms production. Pay attention to energetic and economic efforts can lead to sustainable production. Assuming an investment cost approx. to $80,000 €$ for an air conditioning system with a nominal power of $60 \mathrm{~kW}$, it is possible to estimate an indicative payback period of 6/7 years. Moreover, this data can be used to calculate the evaporated water amount, and consequently to quantify the water needed to be partition during the growth phases, avoiding water waste leading to a sustainable production from the water point of view. The data achieved in this study have to be considered as important input for the further potential design of the conditioning system, considering the scarcity of industrial scale studies in this production chain.

This work can be considered the starting point of a wide research project whose goal is to create an algorithm capable of relating every production input to the final yield result. It should communicate with the growers in real time, displaying the cost of every input, predicting phase duration, mushroom maturation and the final product market value, allowing the producer to save money, time and avoid food waste.

\section{References}

ASHRAE Handbook, 2009. Fundamentals (SI). 36:36.14-36.18.

Colombié S, Malherbe S, Sablayrolles JM. 2007. Modelling of heat transfer in tanks during wine-making fermentation. Food Control 18:953-60.

Giovenzana V, Beghi R, Guidetti R, Fiala M. 2013. Industrial heat pump dryer for chestnuts (Castanea Sativa Mill.): performance evaluation. Appl. Eng. Agric. 29:705-15.

Giovenzana V, Beghi R, Vagnoli P, Iacono F, Guidetti R, Nardi T. 2016. Evaluation of energy saving using a new yeast combined with temperature management in sparkling base wine fermentation. Am. J. Enol. Viticult. 67:308-14.

Giovenzana V, Tugnolo A, Casson A, Guidetti R, Beghi R. 2019. Application of visible-near infrared spectroscopy to evaluate the quality of button mushrooms. J. Near Infrared. Spec. 27:38-45.

Giri SK, Prasad S. 2009. Quality and moisture sorption characteristics of microwave-vacuum, air and freeze-dried button mushroom (Agaricus bisporus). J. Food Process. Pres. 33:237-51.

Gunady MG, Biswas W, Solah VA, James AP. 2012. Evaluating the global warming potential of the fresh produce supply chain for strawberries, romaine/cos lettuces (Lactuca sativa), and button mushrooms (Agaricus bisporus) in Western Australia using life cycle assessment (LCA). J. Clean Prod. 28:81-7.

Noble R, Gaze RH, 1998. Composting in aerated tunnels for mushroom cultivation: Influences of process temperature and substrate formulation on compost bulk density and productivity. Acta Hortic. 469:417-26.

Raghavendra VB, Venkitasamy C, Pan Z, Nayak C. 2017. Functional foods from mushroom. Microb Funct Foods Nutraceutic pp 65-91.

San Antonio JP, Thomas RL. 1972. Carbon dioxide stimulation of 
hyphal growth of the cultivated mushroom, Agaricus bisporus (Lange) Sing. Mushroom Sci. 8:623-9.

Savoie JM, Mata G. 2016. Growing Agaricus bisporus as a contribution to sustainable agricultural development. Mushroom Biotechnology, Academic Press. Ed. Marian Petre, Cambridge, USA pp 69-91.

Sonnenberg AS, Baars JJ, Gao W, Visser RG. 2017. Developments in breeding of Agaricus bisporus var. bisporus: progress made and technical and legal hurdles to take. Appl. Microbiol. Biot.
101:1819-29.

Straatsma G, Sonnenberg AS, Van Griensven LJ. 2013. Development and growth of fruit bodies and crops of the button mushroom, Agaricus bisporus. Fungal Biol-UK 117:697707.

V'zhányó T, Felföldi J. 2000. Enhancing colour differences in images of diseased mushrooms. Comput. Electron. Agr. 26:187-98. 